\title{
A108 オリフィス下流における流れ加速型腐食の評価
}

\section{(1. 流れ場の計測と数値解析)}

\section{Evaluation of the Flow-Accelerated Corrosion Downstream of an Orifice} (1. Measurements and Numerical Analysis of Flow Field)

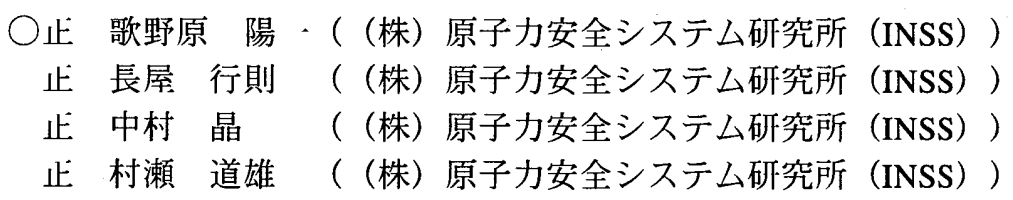

Yoichi UTANOHARA, Yukinori NAGAYA, Akira NAKAMURA and Michio MURASE, Institute of Nuclear Safety System, Inc., 64 Sata, Mihama-Cho, Mikata-Gun, Fukui

\begin{abstract}
In this study, in order to evaluate the effects of flow field on corrosion rate due to flow accelerated corrosion (FAC), an orifice flow was measured and calculated. The diameter of pipe is $50 \mathrm{~mm}$ and that of the orifice is $24.3 \mathrm{~mm}$, and flow velocity in a water loop was set at $2.41 \mathrm{~m} / \mathrm{s}$. Flow field was measured by laser Doppler velocimetry (LDV) and particle image velocimetry (PIV), and compared with a calculation for the same flow conditions. Measurements of wall shear stress downstream of the orifice was also planed. The calculated velocity distributions of standard $\mathrm{k}-[$ agreed qualitatively with PIV data and quantitatively with LDV data. Instantaneous flow field measured by PIV showed vortices around the jet from the orifice and some of them reached near the pipe wall.
\end{abstract}

Key Words: Flow accelerated corrosion, Orifice, Numerical analysis, PIV, LDV, Wall shear stress

\section{1.はじめに}

流れ加速梨腐食(FAC)は、流机が大きく乱される配管 部位で発生するが、これは溶出した鉄イオンの物質輸送が 乱れにより促進され、保謢酸化皮膜の溶解が加速されるこ とが原琂われている。これまで、流れ加速犁腐食(FAC) に刘する流れ場の影響を数值解析で評䛧する研究はいくつ か行われているが(1)(2)(3)、評䛧パラメータとして何を用いる べきなのか、まだ定まった見解はないようである。筆者ら は隇肉速度に直接結びつくパラメータとして、壁面せん断 応小に注目している。というのも、運動量輸送と物質輸送 の相似性を考えると、壁面近傍での運動量輸送量、つまり 壁面せ九断応力が、溶出する鉄イオンの輸送堇に大きく関 遇していると思われるからである。よって、筆者らはオリ フィス下流での炭素鋼腐食速度測定及び流速分布測定 （LDV，PIV）、せん断测定、流れ場の数値解析等によ り、減肉速度と壁面せん断応今の関連性について調べてい る。ここではその内、流速分布測定（LDV, PIV），壁面 せん断測定，および数值解析について述べる。

\section{2. 実験装置}

\section{1 実験ループ}

図 1 に䒠験装置の概要を示す，䒠験装置は高温水タンク 等で構成されるループ, 窒素加圧装置, イオン交換・脱酸 素装置, 水質調整系, 水質测定系等で構成される. 流速分 布測定では常温（約 $20^{\circ} \mathrm{C}$ ）の水をループで循環させるだけ なので，ループと窒素加圧系以外は使用していない．

\section{2 流速分布測定}

流速分布測定の主な目的は, 計算結果の妥当性を検証す るデータの取得である. テストセクションには図 2 でボす アクリル製吅視化試駼体を設置した. 川管内径 $D=50 \mathrm{~mm}$, オリフィス径 $d=24.3 \mathrm{~mm}$ であり, 周用にウォータージャ

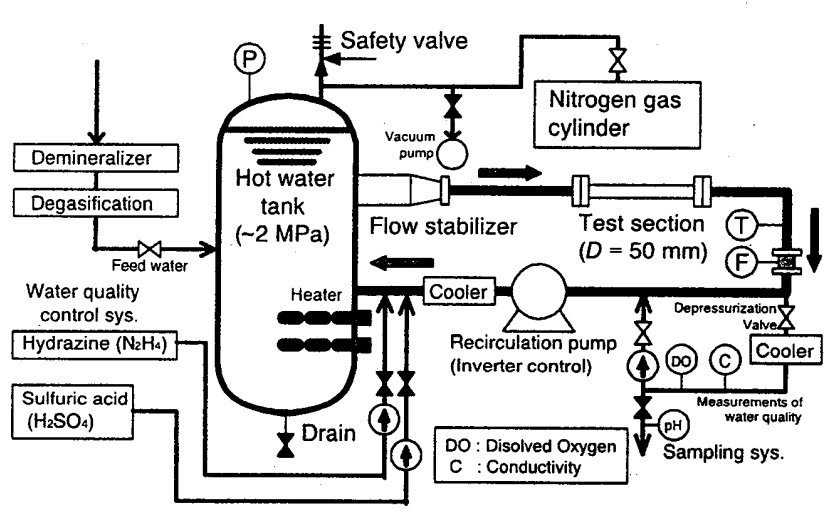

Fig. 1 Test apparatus

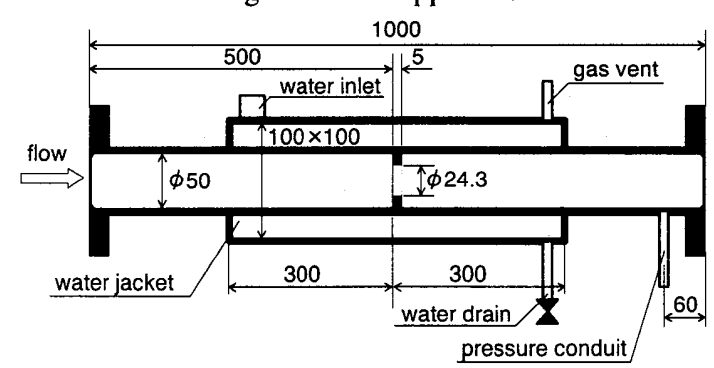

Fig. 2 Test section made of acrylic resin

ケットを付け，流速分布測定時のレーザの屈折を和らげて いる. П視化测定では流量を $Q=17 \mathrm{~m}^{3} / \mathrm{h}$ （管断面平均流 速 $\left.U_{\text {are }}=2.41 \mathrm{~m} / \mathrm{s}, R e=1.2 \times 10^{5}\right)$ に設定し, $0.2 \mathrm{MPa}$ 加圧 することでオリフィス下流でのキャビテーション発生を防 いでいる. 流速分布测定は 2 次元 LDV と 2 次元 PIV (図 3) とで行った。 LDVは日本カノマックス製 Smart-LDV を使 用した。 PIVシステムは，ダブルパルス YAGレーザ（New 


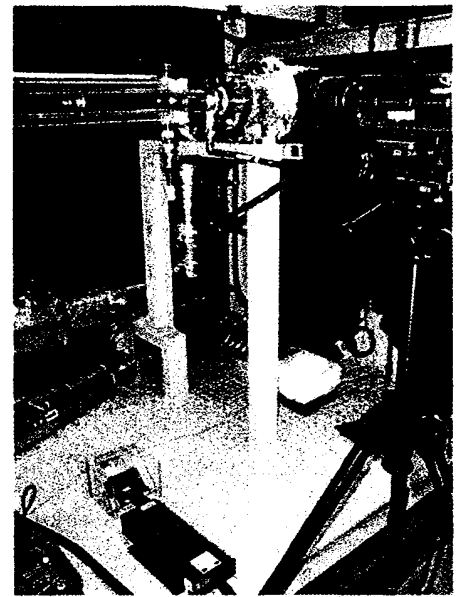

Fig. 3 Picture of experimental set up for PIV

Wave Resarch 製, DPIV-N50，発光時間 3-5nsec），CCD 力 メラ (LaVision 製, Imager Intense, 1376×1040pixel, 10fps)， タイミングユニット (LaVision 製) 等で構成される. LDV 测定サンプル数はおよそ 5000, PIV（時間平均場算出時） は 100 である.

\section{3. 数值解析方法}

数值解析には汎用熱流体解析コード CFX11.0を用いた。 計算領域はオリフィス上流 23D, 下流 31D, 計 54D の領域 である．表 1 に訃算条件の詳細を示す。

\section{4. 結果}

ここでは流れ場に関する結果を中心に述べ，せん断測 定の詳細については講演で述べる.

\section{1 数值解析の妥当性検証}

図 4 はPIVで得られたオリフィス流れの時間平均速度分 布を示したものである.オリフィス上流で縮流され，下流 へ噴流となって噴出している.

図 5 に標準 $\mathrm{k}$-】により得られた速度分布を示す。図 4 と 比較すると，計测された時間平均的な流れ場を定性的に再 現している. 図 6 は軸方向流速を数值解析とLDV 訃測デー タとで比較したものである.SST 乱流モデルを用いた場合

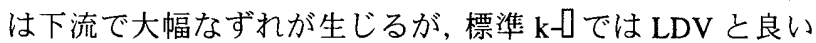
・致を示した。

\section{2 瞬時の流れ場}

図 7 にPIVで訃測された瞬時の流れ場を示す，瞬時では

Table 1. Analysis conditions

\begin{tabular}{|c|c|c|}
\hline \multirow{2}{*}{ 流体 } & \multicolumn{2}{|c|}{ 水 $\left(25^{\circ} \mathrm{C}\right)$} \\
\cline { 2 - 3 } & 密度 & $997 \mathrm{~kg} / \mathrm{m}^{3}$ \\
\cline { 2 - 3 } & 粘性倸数 & $8.899 \times 10^{-4} \mathrm{~Pa} \cdot \mathrm{s}$ \\
\hline 乱流モデル & \multicolumn{2}{|c|}{ Shear Stress Transport $(\mathrm{SST})$, 標準 $\mathrm{k}-[$} \\
\hline \multirow{3}{*}{ 境界条件 } & 流入 & $\begin{array}{c}Q=17 \mathrm{~m}^{3} / \mathrm{h} \\
\left.\text { (管断面平均流速 } U_{\text {ave }}=2.4 \mathrm{~m} / \mathrm{s}\right)\end{array}$ \\
\cline { 2 - 3 } & 流出 & 圧力境界 (平均静圧 $0 \mathrm{~Pa})$ \\
\cline { 2 - 3 } & wall & 壁関数 (一般化刘数則) $\left(y^{+}<100\right)$ \\
\hline 総メッシュ数 & \multicolumn{2}{|c|}{$1,020,307$} \\
\hline
\end{tabular}

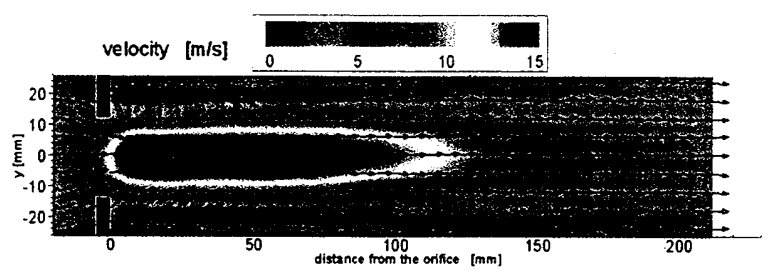

Fig. 4 Time averaged flow field measured by PIV

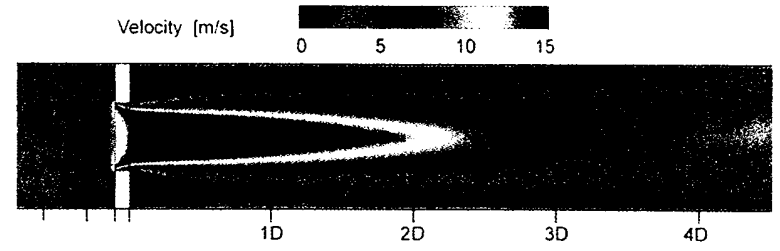

Fig. 5 Calculated velocity distribution

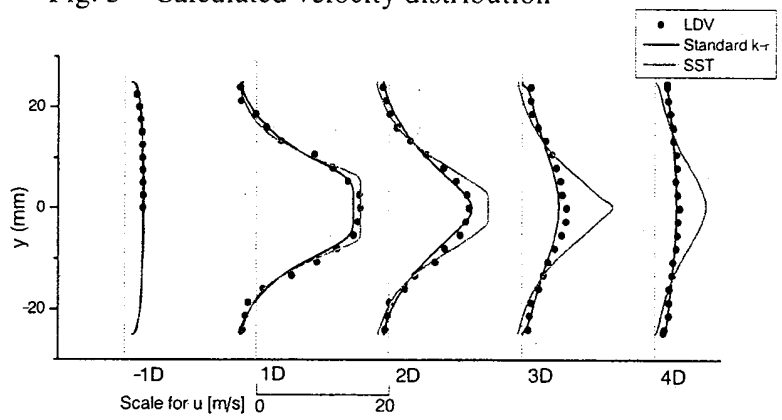

Fig. 6 Axial velocity profiles of standard $k-[$ and LDV

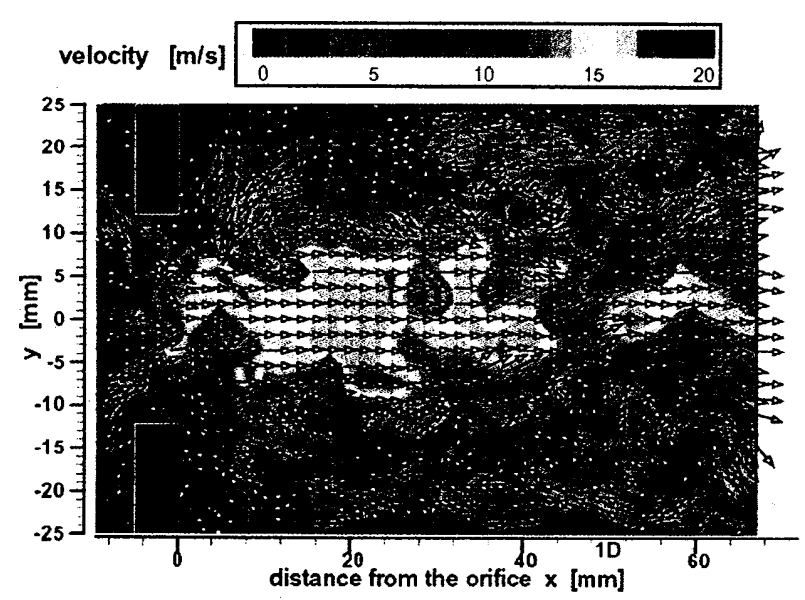

Fig.7 Instantaneous velocity distribution measured by PIV measurement

オリフィスからの噴流の周りに渦が生じており，壁面に到 達する規模の渦も確認できる．配管壁面では妈い逆流が生 じている.このように，定常的な再循環領域のイメージで ある大きく长い渦とは異なっており，噴流周用の渦が壁面 近傍の流れ場に影響を及ぼしていると思われる.

\section{参考文献}

(1)関西電株式会社美浜発電所 3 号機二次系配管破損事 故について(最終報告書)，原子小穴全保安院，2005

(2)米田，電中吥報告，報告書番号 L05007， 2006

(3)矢島ら，材料之環境，56(5)，222-227，2007 